\title{
Lingvistički i geografski prostori u pjesništvu Delimira Rešickog
}

Sažetak: U radu se analiziraju izrazi iz semantičkoga polja vode u pjesništvu Delimira Rešickog. Analizi prethodi pregled dosadašnjih znanstvenih pristupa prostoru kao uvjetu jezičnoj strukturi iz perspektiva lingvistike i fonostilistike. U analitičkom dijelu rada nastojat će se popisanim te iz lingvističke i fonetske perspektive analiziranim izrazima iz semantičkoga polja vode poduprijeti teza o uvjetovanosti jezika životnim prostorom te naglasiti integriranost konkretnoga geografskog prostora Panonije u poetički identitet teksta.

Ključne riječi: prostor, vodni leksik, prostorni odnosi, Delimir Rešicki, panonizam

\section{Uvod}

Odnos jezika i prostora pobuđivao je pozornost i zaokupljao interese tijekom čitave povijesti ljudskoga bavljenja jezikom ne samo teoretičare jezika, osobito one koji su za polazište svoga jezičnoga opisa uzimali značenje, nego čitavu znanstvenu zajednicu. Odnos jezika i prostora nastavak je promišljanja o odnosu čovjeka i prostora, stoga ne čudi činjenica da je gotovo u svakom jeziku pitanje odnosa jezika i prostora konkretizirano na svim razinama jezičnoga opisa.

Teorijski koncept rada odredilo je nekoliko pristupa prostoru: utjecaj prostora na strukturu jezika te gramatičko izražavanje prostora u jeziku; prijenos prostora tjelesnim i osjetilnim iskustvom u jezik; iščitavanje prostornih dimenzija u tekstu uključivanjem geografskoga znanja; pjesnički i stvarni prostor kao rezultat međudjelovanja doživljajnih veza s mjestom te geografski osviješteno preispisivanja prostorne stvarnosti. 


\section{Lingvistički prostori}

Predrag Piper u knjizi Jezik i prostor upućuje na suodnos čovjek jezik - prostor: „Problem prirode odnosa između jezika i prostora deo je problematike odnosa između čoveka i prostora ${ }^{\text {"1 }}$. Govoreći o tome kako potvrdu za dokazivanje tog suodnosa treba tražiti u ,jezičkim činjenicama“ i ,zaključcima koji proističu iz njihove analize“, Piper ističe važnost promatranja iz šire perspektive: „Postoji, ipak, komplementarno stanovište: poznato je, naime, da sve ono što nalazimo u jeziku ne pripada samo jeziku i da se zato pojedine zakonitosti njegovog funkcionisanja mogu posmatrati kao manifestacije opštijih zakonitosti u čovekovom univerzumu“'2.

Istraživanja Z. S. Gunaeva daju podatke o dagestanskim jezicima čiji govornici žive na strmim padinama planina te pokazuju kako se geografija odrazila u gramatičkoj strukturi jezika, odnosno ,...da je prirodna sredina, naročito u ranom periodu razvitka jezika, mogla igrati određenu ulogu ne samo u razvitku leksike, nego i pojedinih elemenata gramatičkog sistema“"3. U dagestanskim jezicima zamjenice, pridjevi i prilozi svojom raznolikošću morfologije daju sliku prostora i prostorne orijentacije u kojemu nastaju. Istražujući dagestanske jezike, posebice lakski jezik, Gunaev nalazi vezu između planinskoga prostora Dagestana i složenoga sustava pokaznih zamjenica. One izražavaju osobitosti toga prostora i ljudskoga snalaženja u njemu preko raznolikosti izražavanja prostorne orijentacije u odnosu na horizintalnu i vertikalnu površinu.

Ruski filolog A. F. Giljferding istražujući jezike govornika prostora Hercegovine došao je do zanimljivih podataka o glagolima kretanja. Giljferding objašnjava kako u svim slavenskim jezicima postoje glagoli sa značenjem ,ići', ,hodati' te glagoli sa značenjem ,pentrati se' ili ,puzati‘ i zaključuje kako se u jeziku govornika hercegovačkoga brdskoga prostora primjećuje prevlast drugih glagola (,puzati', ,pentrati se') na račun prvih (,ići“, ,hodati') te objašnjava: „U Hercegovini je glagol ,ići pješice' gotovo iščezao iz upotrebe. Zamjenjuju ga izrazi ,verati se', ,pe-

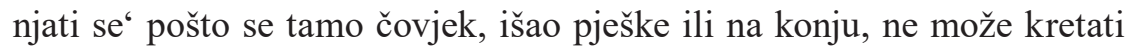
normalno, bez veranja s brda na brdo i pentranja s kamena na kamen. ${ }^{\text {4 }}$

\footnotetext{
${ }^{1}$ Predrag Piper, Jezik i prostor (Beograd: Biblioteka XX vek, 2001), 11.

${ }^{2}$ Piper, Jezik i prostor, 16.

${ }^{3}$ Z. S. Gunaev, „O vyrazenii prostranstvennix otnošenij v nekotoryx dagestanskix jazykax,“ Voprosy jazykoznanija, br. 6 (1977): 126.

${ }^{4}$ Aleksandar Fjodorovič Giljferding, Putovanje po Hercegovini, Bosni i Staroj Srbiji (Sarajevo: Veselin Masleša, 1972), 38.
} 
Branimir Belaj u radu Prostorna značenja na razini složene

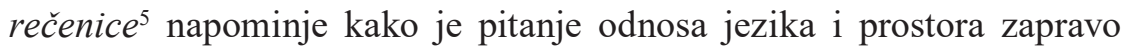
nastavak pitanja odnosa čovjeka i prostora, ističući suodnos jezičnih kategorija i kategorija prostora kao najvažnije aspekte ljudskoga iskustva, mišljenja i spoznaja. Također objašnjava primat prostora kroz činjenicu da je on temeljna ljudska kognitivna domena, iskustvena baza i neizostavni dio svakodnevnoga života te mu upravo to omogućuje da služi kao podloga svim apstraktnijim vidovima kategorizacije.

Govoreći o načinima izražavanja prostora Pranjković kaže: „Kategorija prostora nije se u jezicima morfologizirala, što znači da te kategorije nema (kao posebne gramatičke kategorije) ni na razini oblika riječi ni na razini vrsta riječi, za razliku npr. od kategorija vremena, načina, lica, broja, roda, glagolskoga vida, (ne)određenosti itd."6 Međutim, ističe se da razlog tomu ne treba tražiti u pretpostavci kako je kategorija prostora manje važna od spomenutih već upravo u suprotnome - prostor je možda najvažnija jezična kategorija uopće. Prostorna se kategorija neizravno izražava drugim kategorijama, posebice kategorijom padeža i kategorijom lica: „Te kategorije naime nužno pretpostavljaju i uključuju prostorne relacije ${ }^{\text {"7 }}$. Pranjković dodaje kako se može govoriti o „gramatici prostora“ jer postoje gramatički načini njegova izražavanja od kojih izdvaja morfosintaktički (npr. padežnim oblicima i prijedložno-padežnim izrazima) i sintaktički (rečenicama, složenim rečenicama, međurečeničnim odnosima u tekstu).

\section{Zaokret ka prostoru}

O prostoru se u hrvatskom književnoteorijskom istraživanju ponajviše pisalo u časopisu Glasje koji je s namjerom aktualiziranja problematike prostornosti pokrenuo najveći promicatelj ,zaokreta ka prostoru“ u nas, Stipe Grgas. Zagrebačka slavistička škola posvetila se tematski prostoru u nekoliko navrata. Mnogi kroatistički znanstveni

\footnotetext{
${ }^{5}$ Branimir Belaj, „Prostorna značenja na razini složene rečenice,“ u Prostor u jeziku / Književnost i kultura šezdesetih. Zbornik radova 37. seminara Zagrebačke slavističke škole, ur. Krešimir Mićanović, Zagreb: Zagrebačka slavistička škola (2009), accessed May 13 2017, https://www.hrvatskiplus.org/article.php?id=2531\&naslov=prostor-u-jeziku-knjizevnost-ikultura-sezdesetih.

${ }^{6}$ Ivo Pranjković, Gramatička značenja (Zagreb: Matica hrvatska, 2013), 61.

${ }^{7}$ Pranjković, Gramatička značenja, 61.
} 
radovi u središtu interesa imaju književnu ili jezičnu reprezentaciju prostora. $^{8}$

Stipe Grgas u mnogim svojim radovima ${ }^{9}$ ističući nužnost implementacije prostora $\mathrm{u}$ interdisciplinarna čitanja književnosti, ukazuje i na geografsku dimenziju ljudske egzistencije te nužnost uključivanja geografije u dijalog o prostornosti. Grgas uvodi kulturnu geografiju u interdisciplinarni teorijski dijalog, što Žužul ističe u svome radu: „Upravo je on svojim nastojanjima isposlovao da se ni kod nas više nitko ne libi kulturnu geografiju uplesti u razgovor o književnosti“10.

\section{Prostor u Panonizmu}

U Panonizmu I i Panonizmu II, dvoknjižju autora Gorana Rema i Sanje Jukić, daje se pregled stilskih i stilističkih postupaka autora od 15. stoljeća do danas koji tematsko-motivskim odrednicama pripadaju prostoru Panonije. Riječ je o dvoknjižju koje želi osvijestiti vezu teksta i prostora - prostora Panonije, koji svojom ,geogenezom, posebice količinom vlage kao posljedicom komplesnih geoloških mijena“, ima presliku u tekstovima. Rem i Jukić iščitavaju stilske različitosti i istosti u poetikama autora od Janusa Pannoniusa do Satana Panonskoga. Istosti koje dijele autori okupljeni u dvoknjižju Panonizma mogu se svesti na dva motiva - zemlju i vodu. Voda se etimološki može iščitati i iz imena Panonija: „Naime, smatra se da ime Panonije ima podrijetlo u ilirskome jeziku, iz praindoeuropskoga korijena pen, koji se koristio u riječima

\footnotetext{
${ }^{8}$ Kao npr.: Tvrtko Vuković, „Prostornost Tadijanovićeve poezije: Uvod u spacionalističku analizu," u Tema Tadijanović, Zbornik o Dragutinu Tadijanoviću u povodu 95. pjesnikova rođendana, ur. Vinko Brešić (Slavonski Brod: Matica hrvatska Slavonski Brod, 2002), 1319.; Sanjin Sorel, Mediteranizam tijela (Zagreb: altaGama, 2003.); Ivana Žužul, „Zaglavljeni u distopiji. Otok kao mjesto bez mjesta u Šoljanovu Na Pelegrinu i Karuzinu Vodiču po otoku,“ u Hvar - književnost i kazalište, ur. Dubravko Jelčić, Boris Senker i Vinka Glunčić -Bužančić (Zagreb - Split: Hrvatska akademija znanosti i umjetnosti - Književni krug, 2012), 341-360.

${ }^{9}$ Spomenut ću samo neke: Stipe Grgas, „Posvećenje prostora kao ljudska praksa,“ Glasje: časopis za književnost i umjetnost, br. 13 (2003): 43-51.; Stipe Grgas, Kažnjavanje forme: irsko pjesništvo poslije Yeatsa (Zagreb: Naklada MD, 2006).; Stipe Grgas, „Bučno nadire prostor sa svih strana: Geografija u pjesništvu Adriane Škunca,“ u Muzama iza leđa: čitanje hrvatske lirike, ur. Tvrtko Vuković (Zagreb: Zagrebačka slavistička škola, 2010), 51-69.; Stipe Grgas, „O hrvatskome spacijalnom imaginariju,“ u Mjesto, granica, identitet: Prostor u hrvatskoj književnosti i kulturi, ur. Lana Molvarec (Zagreb: Zagrebačka slavistička škola, 2014), 49-66.

10 Žužul, „Zaglavljeni u distopiji,“ 342.
} 
močvara, voda, mokro"11. Geomorfologija je, mogli bismo zaključiti, bila najutjecajniji sudionik formiranja Panonizma na tematsko-motivskome te leksičko-semantičkome planu.

\subsection{Hidrobiografija prostora Panonije}

Istočni dio Hrvatske oblikovale su rijeke Dunav, Drava i Sava koje su ujedno i granice Slavonije, Baranje i Srijema. Hrvatski prostor Panonije, odnosno Slavonije i Baranje prostor je međurječja koji je određen vodom. Nizinski i ravničarski dijelovi, slijedeći tokove Dunava, Drave i Save nalaze se u istočnoj Slavoniji i Baranji. To je područje obilježeno gustom mrežom manjih rijeka, dugih i vijugavih: Bosut, Vuka, Karašica, Vučica, Biđ, Orljava, Londža te brojnim potocima, starim koritima i kanalima. Ove su površine riječnih rukavaca, jezera i bara stalno ili povremeno pod vodom ${ }^{12}$.

\section{Prostor Panonije i Delimir Rešicki}

Delimir Rešicki rođen je 16. ožujka 1960. u Osijeku. Studij kroatistike završio je na tada Pedagoškome, danas Filozofskome fakultetu $\mathrm{u}$ istome gradu. Poeziju, prozu, književnu kritiku te medijsku publicistiku i esejistiku počeo je objavljivati početkom osamdesetih godina u svim važnijim hrvatskim časopisima. Prevođen je na brojne jezike: njemački, engleski, talijanski, francuski, švedski, španjolski, mađarski, poljski, slovački, ruski, bugarski, makedonski i slovenski. Pjesničkim, proznim i esejističkim tekstovima zastupljen je u pedesetak antologija, pregleda i panorama suvremene hrvatske poezije, proze i esejistike, kao i internacionalnim antologijama i pregledima europskoga i svjetskoga pjesništva. Objavljene knjige pjesama: Gnomi (1980), Sretne ulice (1987), Die die my darling (1990), Knjiga o anđelima (1997), Ezekijelova kola (1999), Aritmija (2005), Meghalni a pandakkal (izbor, 2008), Arrhythmie (2008), Crne marame (izbor, 2008), Aritmija (2013), Zaspati u Dobovi (izbor, 2013), Lovci u snijegu (2015) ${ }^{13}$.

\footnotetext{
${ }^{11}$ Sanja Jukić i Goran Rem, Panonizam I (Budimpešta - Osijek: Krešendo, 2014), 31.

${ }_{12}$ Damir Magaš, Geografija Hrvatske (Zadar: Sveučilište u Zadru, Meridijani, 2013), 133.

${ }^{13}$ Delimir Rešicki, Gnomi (Zagreb: cddssoh, 1985).; Delimir Rešicki, Die die my darling (Zagreb: Biblioteka quorum, 1990).; Delimir Rešicki, Knjiga o anđelima (Zagreb: Meandar, 1997).; Delimir Rešicki, Ezekijelova kola (Zagreb: Biblioteka itd, 1999).; Delimir Rešicki, Sretne ulice (Zagreb: Meandar, 2000).; Delimir Rešicki, Aritmija (Zagreb: Meandar, 2005).; Delimir Rešicki, Lovci u snijegu (Zagreb: Fraktura, 2015).
} 
Žarko Paić14 karakterizira poeziju Rešickoga kao onu koja je „prostornošću“ i „unutarnjim doživljajem krajolika“ odredila svoj jezik. Istu zbirku komentira Tea Benčić Rimay ${ }^{15}$ kao ,jeku opasnog prostora“: „Sada se u njegovoj poeziji osjeća, Gotovčevim riječima rečeno, jeka opasnog prostora. (...) Jeka opasnosti prostora logičan je slijed poetike krajputaša hrvatske poezije, tako malo poznata, a tako izvanredna pjesnika kakav jest Delimir Rešicki“.

\section{Prostor i govor}

Prostor se, kao jedno od temeljnih iskustava ljudskog doživljaja i poimanja svijeta, očituje u jeziku. Ideju da je upravo on jedna od temeljnih intuicija usađenih u našu prirodu nije zaobišla ni fonetika. Mihovil Pansini ${ }^{16}$ u radu Koncept gramatike prostora svodi protežnost verbalnih događaja i gramatičkih odnosa na prostorne događaje i prostorne odnose: „Verbalni jezik samo je jedan od korespondentnih jezika kojima komuniciramo između sebe i sa svijetom. U događaju najvažniji je prostor, u stvaranju govora također, a posrednik između svijeta i verbalnog govora sustav je za percepciju prostora." Pansini objašnjava pojam spaciocepcije te kreće od senzorike kao biološke reakcije na podražaj - osjetilnost (odziv bilo čega na bilo što). Uspoređujući događaj s verbalnim jezikom Pansini kaže kako rečenica ima četiri ista elementa: predmet, prostor, vrijeme i uzročnost te ih uspoređuje s imeničkim pojmovima i glagolskim pojmovima koji su u uzročno-posljedičnoj vezi i događaju se u vremenu i prostoru.

\section{Prostor pjesme}

U okviru fonetike razvijen je teorijski pristup koji analizira poetske tekstove te definira „prostor pjesme“ kroz višedimenzionalnost pjesničkoga znaka. Iz fonostilističke teorije pjesništva proizlazi sljedeća veza poezije i prostora: pjesnički znak preko svoje materijalnosti, materijalne sličnosti te jednakosti i blizine unutar zatvorenoga teksta

\footnotetext{
${ }_{14}$ Žarko Paić, „Praskozorja i ledeni grobovi, ogled uz zbirku pjesama Delimira Rešickog Aritmija,“ Riječi, br. 3/4 (2005): 94-99.

15 Tea Benčić Rimay, „Jeka opasnog prostora,“Vijenac, br. 301 (2005) ), accessed May 13, 2017 https://www.matica.hr/vijenac/301/JEKA OPASNOG PROSTORA/.

${ }^{16}$ Mihovil Pansini, „Koncept gramatike prostora,“ Govor, br. 5 (1988): 117.
} 
pjesme uspostavlja odnose i veze s drugim znakovima, međusobnim odražavanjima i sadržanjima. Prostornost i simultanost osobine su pjesničkoga znaka koje dokidaju linearnost i vremensku dimenziju jer se više sadržaja ostvaruje $u$ istome vremenu tvoreći plošnost ili prostornost pjesničkoga teksta - spacijalnost. Branko Vuletić ${ }^{17}$ u fonostilističkim tumačenjima pjesničkih poetskih tekstova inzistira na motiviranosti i spacijalnosti govornoga znaka u suprotnosti s arbitrarnošću i linearnošću jezičnoga znaka, dok pjesnički znak, blizak govornome, osim individualnih i motiviranih odnosa uspostavlja i kreativne odnose između izraza i sadržaja koji prenosi. Vraćanjem, na koje nas upućuju unutarnje motivirani odnosi, uspostavljaju se nelinearni smjerovi čitanja pjesničkog teksta, uspostavlja se prostor pjesme. Prostor pjesme ostvaruje se materijalnom sličnošću označitelja i njihovom blizinom te Vuletić pjesmu definira kao ,zatvorenu cjelinu u kojoj su bitni odnosi između pojedinih dijelova, a ne veza pojedinih dijelova $\mathrm{s}$ vanjskim svijetom." ${ }^{\prime 18}$ Prostor pjesme grade postupci: odražavanje, ponavljanje, sažimanje. ${ }^{19}$

\section{Leksik vodnih prostora}

U abecednom pregledu ekscerpiranih riječi obuhvatili smo imenske, glagolske, pridjevske i priložne lekseme. Leksička analiza pokazuje koji su leksemi, ekcerpirani iz sedam zbirki pjesama, obuhvaćeni u semantičko polje vode. U popisu ekscerpiranih leksema, uz definiciju svakoga pojedinog leksema, dajemo i mjesto pojavljivanja u zbirkama pjesama. Ukupno je ekscerpiran 251 leksem. Najveći broj leksema pripada imenskim leksemima, dok je najmanji broj priložnih. Od ukupno dvjesto pedeset i jednog (251) vodnog leksema koji se javljaju kroz devetsto pedeset i osam (958) pojavnica, konkordancija leksema pokazala je sljedeću brojnost vodnih leksema u pjesničkome opusu Delimira Rešickog: Die die my darling: 202, Lovci u snijegu: 159, Ezekijelova kola: 145, Sretne ulice: 133, Knjiga o anđelima: 121, Aritmija: 99, Gnomi: 99.

\footnotetext{
${ }^{17}$ Branko Vuletić, Jezični znak, govorni znak, pjesnički znak (Zagreb: Izdavački centar Revija Radničkog sveučilišta Božidar Maslarić, 1988).; Branko Vuletić, Prostor pjesme: o plošnom-prostornom ustrojstvu pjesništva Jure Kaštelana (Zagreb: Biblioteka „L“. Zavod za znanost o književnosti Filozofskoga fakulteta, 1999).

${ }^{18}$ Branko Vuletić, Fonetika pjesme (Zagreb: FF press, 2005), 254.

${ }^{19}$ Branko Vuletić, Prostor pjesme.; Branko Vuletić, Fonetika pjesme.
} 


\section{Semantika vodnih prostora}

U semantičkom polju vode, kako je vidljivo iz prethodnoga poglavlja, okupljeni su imenski, glagolski, pridjevski i priložni leksemi. Pri ekscerpiranju izraza potrebnog za semantičku analizu iz ukupnoga leksika vezanog uz pojam ,voda“ odvojili smo imenske lekseme te ih podijelili u dvanaest semantičkih gnijezda. Ostale skupine leksema (glagolske, pridjevske, priložne) nismo obuhvatili u semantičkoj analizi. Izdvojili smo onu skupinu leksema koja je za naše istraživanje najrelevantnija, a to je skupina imenskih leksema koji ili sami jesu vodna geografska nazivlja (npr. more, rijeka, jezero i dr.) ili su sadržajem vezani uz vodna geografska nazivlja (npr. pučina, plima, hrid i dr.).

Uzimajući u obzir podjele na semantička gnijezda i skupine koje nalazimo kod D. Brozović Rončević ${ }^{20}$, podijelili smo imenski vodni leksik na ukupno dvanaest semantičkih gnijezda. Dvanaest semantičkih gnijezda podijelili smo u dvije skupine. Prvu skupinu, Zemljopisna vodna nazivlja, čine tri gnijezda imenskih leksema: 1. Zemljopisno nazivlje vezano uz more, podmorje te dodir kopna i mora, 2. Protočne vode, te 3. Zbirališta vode. Druga skupina, Ostali vodni leksemi, okuplja devet gnijezda koja su na različite načine vezana uz pojam vode: 1 . Voda, 2. Agregatna stanja vode, 3. Oborinske vode, 4. Tjelesne vode, 5. Imenski leksemi koji znače naprave, objekte ili predmete, osobe, prostore i djelatnosti vezane uz pojam „voda“, 6. Flora, 7. Fauna, 8. Hidronimi, 9. Leksemi iz dvaju ili više gnijezda.

Podjela vodnih imenica iz skupine Zemljopisna vodna nazivlja prema semantičkim gnijezdima pokazuje najveću brojnost imenica u semantičkome gnijezdu Zemljopisnoga nazivlja vezanoga uz more, podmorje te dodir kopna i mora, a najmanju imenica u semantičkome gnijezdu Zbirališta vode.

Rezultati analize pokazuju kako su brojnije imenice u skupini Ostali vodni leksemi (473) u odnosu na skupinu Zemljopisna vodna nazivlja (196). Imenica koja ima najveći broj pojavnica, snijêg (84), nalazi se u skupini Ostali vodni leksemi odnosno u semantičkome gnijezdu Oborinske vode, a slijedi ju imenica môre (82) iz skupine Zemljopisna vodna nazivlja odnosno semantičkoga gnijezda Zemljopisno nazivlje vezano uz more, podmorje te dodir kopna i mora.

\footnotetext{
${ }^{20}$ Dunja Brozović Rončević, „Apelativi u hrvatskoj hidronimiji“ (doktorska disertacija, Filozofski fakultet Zagreb, 1997).
} 


\section{Gramatika vodnih prostora}

Potreba za lokalizacijom i autolokalizacijom jedna je od osnovnih ljudskih potreba te se oduvijek postavljala kao zahtjev jezičnome izražavanju. Još iz antičkih vremena datiraju ideje o prostornom kao temeljnom i polazišnom značenju padeža te da se ostala značenja različitim tipovima metaforizacija izvode iz prostornih. Među prvima ih je opisao bizantski gramatičar Maksim Planud krajem 13. i početkom 14. stoljeća. Mnogi su znanstvenici dovodili u vezu ljudsko poimanje prostora i njegovo preslikavanje u jezik, potrebu za autolokalizacijom i prijenosom izvanjezične stvarnosti u strukturu jezika preko prostornoga izražavanja.

Kategorija prostora se u jezicima nije morfologizirala te je nema kao posebne gramatičke kategorije. Pa iako je nema ni na razini vrsta ni oblika riječi može se smatrati da je kategorija prostora „,najvažnija jezična kategorija uopće“"21 te da se, kao u okviru lokalističke teorije padeža ili opće teorije semantičkih lokalizacija, prostorna kategorija smatra temeljnom, onom iz koje se druge kategorije izvode. Upravo zbog toga što se kategorija prostora smatra onom iz koje se izvode druge kategorije, „tragovi“ se prostora mogu naći i u drugim morfološkim kategorijama (npr. kategoriji padeža ili kategoriji lica). U tim kategorijama, koje uključuju prostorne relacije, mogu se pronaći prostorna značenja. Kategorijom padeža izražavaju se prostorni odnosi među predmetima, uz određene pretpostavke o suodnosima objekta lokalizacije (OL) i lokalizatora $(\mathrm{L})^{22}$. Kategorija lica, također preko sudionika govornog čina koji se nalaze u nekom prostoru, izražava prostor. Prostorna se značenja gramatičkim načinima izražavaju morfosintaktički, npr. pojedinim padežnim oblicima i prijedložno-padežnim izrazima, ili sintaktički, rečenicama, složenim rečenicama, suodnosima rečenica u tekstu.

Prostorna značenja obično imaju tri primarna elementa: objekt lokalizacije (OL), tj. predmet koji treba smjestiti u prostor; lokalizator (L), tj. predmet uz pomoć kojega se objektu lokalizacije nalazi mjesto, sredstvo lokalizacije; te konkretizator $(\mathrm{K})$ ili orijentir, tj. element kojim se konkretizira mjesto OL u odnosu na L. Konkretizator (K) daje obavijest o tome u kakvom je odnosu OL u odnosu na $\mathrm{L}$, je li unutar ili izvan L, je li mu s prednje ili stražnje strane, je li blizu njega ili nije

\footnotetext{
${ }^{21}$ Pranjković, Gramatička značenja, 60.

22 Pranjković pojašnjava: „da se objektu lokalizacije utvrđuje mjesto uz pomoć lokalizatora, a mjesto lokalizatora smatra se poznatim, uglavnom zahvaljujući govornom činu“. Pranjković, Gramatička značenja, 61.
} 
itd. Prostorna se značenja najčešće izražavaju prijedložno-padežnim izrazima upravo zato jer oni sadrže spomenuta tri elementa (OL, L, K).

S obzirom na dominantni sem u suodnosu OL i L te druge semantičke parametre (npr. kontaktnost/distaknost, lice/naličje, dinamičnost/ statičnost, direktivnost/nedirektivnost i dr.) u hrvatskom se jeziku izdvaja dvadeset konkretnijih odnosa koji se označavaju i/ili konkretiziraju prijedlozima. ${ }^{23}$

\subsection{Vodne imenice u prijedložno-padežnim izrazima}

Od sedam padeža hrvatskog jezika pet ih se pojavljuje u izražavanju prostora. To su kosi ili nesamostalni padeži: genitiv, dativ, akuzativ, lokativ, instrumental. Svaki padežni oblik svojim značenjem može utjecati na značenje cijeloga prijedložno-padežnog izraza.

Najveći se broj vodnih imenica, iz skupine Zemljopisno vodno nazivlje koje u prijedložno-padežnom izrazu s prostornim značenjem imaju funkciju lokalizatora, nalazi u genitivu (27), dok ih je najmanji broj u dativu (4) i instrumentalu (4). Najbrojnije vodne imenice, u genitivu, iz semantičkoga su gnijezda Zemljopisno nazivlje vezano uz more, podmorje te dodir kopna i mora.

\subsection{Podjela prijedložno-padežnih izraza koji sadrže vodne imenice prema prostornim odnosima}

U sastavu prijedložno-padežnih izraza podijeljenih prema prostornim odnosima nalaze se ekscerpirane imenice iz skupine Zemljopisna vodna nazivlja u tablici prikazani prema broju pojavljivanja:

\begin{tabular}{|l|c|c|c|}
\hline \multicolumn{1}{|c|}{ Prostorni odnosi } & $\begin{array}{c}\text { Zemljopisno nazivlje } \\
\text { vezano uz more, podmorje } \\
\text { te dodir kopna i mora }\end{array}$ & Protočne vode & Zbirališta vode \\
\hline prelokativnost & & & 1 \\
\hline supralokativnost & 12 & 4 & 1 \\
\hline sublokativnost & 3 & 3 & \\
\hline intralokativnost & 13 & 4 & 6 \\
\hline adlokativnost & 2 & 5 & \\
\hline ultralokativnost & 1 & & \\
\hline lateralna lokativnost & 1 & & \\
\hline
\end{tabular}

${ }^{23}$ Ivo Pranjković, Druga hrvatska skladnja. Sintaktičke rasprave (Zagreb: Hrvatska sveučilišna naklada, 2001), 9 . 


\begin{tabular}{|l|c|c|c|}
\hline prolokativnost & 1 & 1 & \\
\hline cirkumlokativnost & 1 & & \\
\hline translokativnost & 1 & & 1 \\
\hline interlokativnost & 1 & & \\
\hline direktivna lokativnost & 7 & 4 & 3 \\
\hline ablokativnost & 5 & & $\mathbf{1 2}$ \\
\hline
\end{tabular}

Tablica 9. Podjela imenica s prijedložno-padežnim izrazima prema broju pojavljivanja u prostornim odnosima

Nekoliko primjera intralokativnosti (OL (objekt lokalizacije) nalazi se unutar ili u granicama L (lokalizatora) ili se kreće prema njegovoj unutrašnjosti):

- zemljopisno nazivlje vezano uz more, podmorje te dodir kopna i mora:

A (54) more: čekajući da te bar / jednom čuje i bude ti blizu bedara / u more danja / potonula sjena.

A (35) more: Tko pije vodu s tih zdenaca / može kazati da vidio je djelić čistog neba / u moru koje skupa sa mnom šuti

- protočne vode:

LS (38) zdenac: Taj neznanac mora baš tim alatom (...) $i$ dolje u presahle zdence / na bilo čemu napisati tek jedno jedino slovo

EK (80) zdenac: tamo gdje lan / pokriva vodu uzdencu iz kojega piju anđeli

- zbirališta vode:

A (40) lokva: Žuta svjetla McDonald'sa / u lokvama nakon pljuska u Varšavi

LS (194) močvara: ali mora postojati način da vam zalutalome u drevnoj močvari / put ne obasjava tek anđeo smrti koji sja.

Analiza koja dijeli vodne imenice u sastavu prijedložno-padežnih izraza prema prostornim odnosima pokazuje najveću brojnost primjera (48) iz semantičkoga gnijezda Zemljopisno nazivlje vezano uz more, podmorje te dodir kopna i mora. Imenice u sastavu prijedložno-padežnih izraza iz toga gnijezda pokazuju najveću brojnost u prostornom odnosu intralokativnosti (13) u kojemu OL nalazi se unutar ili u granicama L ili se kreće prema njegovoj unutrašnjosti. 


\section{Vodni prostori unutar prostora pjesme}

Prostor pjesme definiran je u fonetici kao prostor koji se gradi materijalnošću označitelja i počiva na motiviranim povezivanjima pojedinih dijelova pjesničkoga teksta. Materijalnost označitelja može biti glasovna, ritmička ili govorna te ona, gradeći prostor pjesme, potvrđuje pjesmu kao zatvorenu cjelinu u kojoj su bitni odnosi između pojedinih dijelova pjesme, a ne veza pojedinih dijelova s vanjskim svijetom. ${ }^{24}$

Ponavljanje je ključni princip građenja pjesme i ishodište motiviranosti pjesničkoga znaka. Motivirani odnosi u pjesmi ne ostvaruju se vezama označitelja i označenog, već materijalnim vezama između pojedinih dijelova teksta - pjesnička se sintaksa oblikuje postupcima unutarnje motiviranosti. Pjesnički znak stvara svoj vlastiti svijet nastojeći uspostaviti što više materijalnih veza preko sličnosti glasovnoga sastava i sadržaja - ali ne sličnosti jezičnih ili izvanjezičnih sadržaja, već onih koji u pjesmi, motivirano povezani, postaju jednakovrijedni. Povezivanje različitih sadržaja preko sličnosti i blizine njihovih označitelja Vuletić naziva glasovnom metaforom.

U razdijelu koji slijedi pokušat ćemo prikazati odražavanja i ponavljanja kao načine i postupke kojima se gradi prostor pjesme u pjesništvu Delimira Rešickog.

\subsection{Odražavanja i ponavljanja}

Odražavanja dijelova pjesme tvore zrcalne strukture, zrcalne odraze ili jednostavna ponavljanja glasova - postupci asonance, aliteracije, homofoni, anagrami koji čine ključne postupke građenja pjesničkoga prostora. Odnosno, svi postupci odražavanja upućuju na unutarnju motiviranost kao najbitniji postupak građenja pjesme - jedan se dio teksta odražava u drugome, jedan se sadržaj odražava u drugom sadržaju, oni se međusobno uključuju i tako tvore motiviran, slojevit simultan znak.

Ponavljanje je u osnovi svih pjesničkih postupaka gradnje pjesničkoga prostora. Ono dovodi u vezu elemente na različitim mjestima unutar prostora pjesme među kojima se uspostavljaju odnosi preko materijalnosti znaka te se tako oblikuje prostor pjesme. Glasovne figure, djelujući svojim međusobnim sličnostima, stvaraju unutarnje motivirane povezanosti u kojima je osnovna sprega blizina, a potom sličnost. Stoga metafore mogu biti obilježja metonimija jer ih povezuje sličnost - ali sličnost glasovnoga sastava (asonanca, aliteracija i sl.), a ne sličnost

\footnotetext{
${ }^{24}$ Vuletić, Fonetika pjesme, 254.
} 
predmeta s vanjskim svijetom. Načelo blizine upućuje i na činjenicu da veze prema sličnosti nikada ne izlaze izvan granica pjesničkoga teksta. Ono što je zajedničko riječima koje čine metonimiju jest kontekst ili prostor pjesme u kojoj se nalaze.

Pjesma Proljetno more, Vrsar artikulirana je u deset rečenica od kojih prva traje sedam stihova, druga i treća četiri, četvrta tri stiha, peta šest stihova, šesta osam, sedma tri, deveta i deseta pet stihova te deseta osamnaest. U pjesmi je uočljiva okomito ustrojena nepravilna zrcalna struktura koja počinje naslovom s imenicom more koje se ponavlja četiri puta tijekom cijele pjesme uključujući i naslov te veže sve dijelove pjesme u cjelinu dajući svakome dijelu drugačije značenje. U prvom dijelu pjesme imenica more (s desne je strane ceste proljetno more) anagramskim postupkom i blizinom riječi (večernjega) umora (koja sadrži imenicu more) upućuje na osjećaj zatvorenosti, nijemosti i nemoći. U drugom dijelu, okružena vodnim riječima (šterne, pije, vodu, $s$ dna zdenaca, ribarske brodice, usidrene u marini, u rukavcu Drave, ledom, injem), imenica more kao da stvara vodni prostor u kojemu spaja vodna obilježja panonskoga prostora te nagovještava mogućnost promjene atmosfere pjesme. U posljednjem dijelu pjesme u kojemu se nalazi imenica more blizinom i sličnošću glasovnoga sastava vezuje se uz pridjev vlažnim (stijenkama) te kao da do samoga kraja pjesme održava vodenost kao presliku panonskoga krajolika.

Postupak odražavanja uočavamo u ponavljanju glasa š u središnjem dijelu pjesme koja motivirano povezuje riječi te materijalnom sličnošću tvori unutrašnje motivirani okomit niz. Riječi koje sadrže glas š ponavljaju se i okupljaju u početnom, središnjem i posljednjem dijelu pjesme: u prvome dijelu pjesme glas $\breve{s}$ povezuje riječi: groš, ušiven, što, zašivene, što s riječima iz središnjega dijela: iščezloga, šterne, šuti, mreška, pokušaju, nezavršenoj, slušao, te upućuju na razrješenje (što - nešto; pokušaju-završava; slušao - ravnodušnost) u riječima koje sadrže glas $\check{s}$ u posljednjem dijelu pjesme: što, što, završava, ravnodušnost, nešto, nešto što, nešto što.

Proljetno more, Vrsar Zvonku Makoviću

Kao groš ušiven u odjeću onoga koji je jednom morao prijeći mnoge granice suočen samo sa svojom bijedom 
i samo sa svojim strahom

skriveno je sve ono

što sam ti ikada poželio reći.

Ti si konac

nevidljiva lanena nit

kojom su i danas

zašivene moje usne.

Crvena zemlja čijim su prahom

označene stranice

izgubljenih glagolskih brevijara

boje je večernjega umora u tvojim očima.

Sav meni poznat svijet

nestaje u retrovizoru

$\mathrm{s}$ desne je strane ceste proljetno more.

Odnekud iz vremena

skrivenog u žbuci

što se polako drobi

između kamena i kamena

stići će kosac i stići će janje bez očiju.

Haljina iščezloga anđela

pokrit će šterne kilometrima uokrug

mjesta na kojemu smo zastali.

Tko pije vodu s dna tih zdenaca

može kazati da vidio je djelić čistog neba

u moru koje skupa sa mnom šuti

i ne mreška ribarske brodice

usidrene u marini.

U rukavcu Drave

vidjeh početkom zime mrtvoga labuda

okovanoga ledom i i injem.

Sličio je, na neki neobičan

ali sasvim izvjestan način

nezavršenoj Mozartovoj Velikoj misi 
koju sam slušao s CD-a

$\mathrm{u}$ tvome automobilu.

Ono odkuda sam daleko je

ono kamo idem nestaje i vraća se

kada začas sklopim oči

kao slika na pokvarenom hotelskom televizoru

odmah iza ponoći.

R. M. Rilke nije nikada napisao

precizne upute

za dostojanstveno pjesničko starenje

$i$ to je ona karika

koja nedostaje u mome

pokušaju progovora o onome

što mi se zapravo

dogodilo prije, mnogo prije

nego što sam shvatio gdje počinje

i završava zaborav

ravnodušnost od koje me

zalud liječi more

ti bijeli prohladni zidovi

plijesan na njihovim vlažnim stijenkama

tvoja soba u kojoj je mir

nešto sasvim obično

nešto što se ne poklanja

nešto što se ne prepoznaje u slučaju.

Učestalost glasa $\check{s}$ u prvome dijelu pjesme iznosi $1,98 \%$, što je neznatno više od njegove učestalosti u neutralnom kontekstu ${ }^{25}$ koja iznosi 1,19 - 1,50, u drugome dijelu pjesme učestalost glasa š iznosi 2,02\%, a u posljednjem dijelu pjesme $3,19 \%$. Najizraženija je učestalost glasa $\check{s}$ u središnjem dijelu pjesme - $3,84 \%$, u prvim dvama stihovima središnje strofe te u šestom i sedmom stihu 4,16 \%. Upravo u toj središnjoj strofi aliteracija glasa $\breve{s}$ otkriva svoje značenje - motivirano povezivanje riječi različitog sadržaja i uočavanje veze među njima: iščezloga-šterne;

${ }_{25}$ Podatci o učestalosti glasova u neutralnom kontekstu dalje u tekstu iz istoga izvora: Dušanka Vuletić, Istraživanje govora (Zagreb: Fakultet za defektologiju Sveučilišta u Zagrebu, 1991). 
šuti-mreška parovi su riječi koji ukazuju na promjenu, čišćenje, ispiranje te prekidanje šutnje zvukom mreškanja mora. Aliteraciju glasa $\check{s}$ pojačava anagramski postupak već na početku prvoga stiha pjesme u riječima groš ušiven u kojima se blizinom i sličnošću uočavaju oš i uš. Anagramski postupak uočava se i u riječima što - nešto na početku pjesme (što sam ti ikada poželio reći), a potom na samom kraju što (ponavlja se šest puta u pjesmi) te nešto koje sadrži što (nešto sasvim obično/nešto što se ne poklanja/ nešto što se ne prepoznaje u slučaju). Nešto se pojavljuje u obliku anafore na početcima posljednjih triju stihova, istaknuta grafičkim odvajanjem praznim retcima. Anafora koja stvara eufonični ustroj stihova ističe mir (tvoja soba u kojoj je mir) iz prethodnoga stiha kao rješenje ravnodušnosti i šutnje koje kroz čitavu pjesmu ponavljanjem glasa š motivirano vezuju riječi ušiven, zašivene, iščezloga, šuti, nezavršenoj, završava, ravnodušnost, pokušaju.

Pjesma je na nekoliko mjesta pisana u drugom licu što označava krajnji oblik konativne funkcije jezika: ${ }^{26}$ Ti si konac... boje je večernjega umora u tvojim očima ... u tvome automobilu... tvoja soba u kojoj je mir. Takvo obraćanje: neostvarivanje dijaloga, poticanje na dijalog, pitanja bez odgovora stvara napetost koja se rješava angažiranim sudjelovanjem čitatelja odnosno „razrješava krikom, krajnje bogatim i krajnje angažiranim oblikom ljudskog govorenja“ ${ }^{27}$.

Središnji dio, vrhunac pjesme, sadrži odražavanje u riječima kosac, zdenaca, brodice, rukavcu koje su kroz čitavu pjesmu motivirano povezane konsonantom $c$ preko riječi granice, konac, crvena, stanice, ceste, $C D$-a, precizne. Odražavanje se prepoznaje u postupku vanjske motiviranosti, preko riječi koje sadrže visoki, svijetli glas $\boldsymbol{c}$, te se poistovjećuju sinestetskim postupkom s tankoćom konca, oštrinom kose (kosac), rubnošću granice (granice, stanice, ceste). Istovremeno, riječi koje sadrže visok i svijetao glas $c$ pokazuju u svome materijalnom sastavu i dominantnost tamnog i niskog glasa $\boldsymbol{n}$ što simbolizira kontrapunkt suprotnosti (granice, stranice, zdenac): neposredna blizina svijetlog glasa $c$ akustičkom i auditivnom vrijednošću suprotstavlja metaforičke vrijednosti s tamnim glasom $\boldsymbol{n}$. U središnjem dijelu pjesme također se uočava dominantnost glasa $\boldsymbol{m}$ (kilometrima, mjesta, kojemu smo, može, moru, sa mnom, ne mreška, marini) koji je najniži suglasnik te motivirano povezujući riječi uspostavlja odnos među pojedinim dijelovima

\footnotetext{
${ }^{26}$ Vuletić naglašava isto: „Drugo lice uvijek sadrži i prvo: u naglašenoj konativnoj funkciji - izravnom obraćanju, prvo i drugo lice međusobno se uključuju, poistovjećuju: njihova je emotivna angažiranost jednaka." Vuletić, Fonetika pjesme, 95.

${ }^{27}$ Vuletić, Fonetika pjesme, 95.
} 
pjesme. Spomenuti konsonanti $\boldsymbol{m}$ i $\boldsymbol{n}$ svojom nazalnošću doprinose tečnosti stiha i materijaliziraju neprekidnu zvučnost što stvara dojam protoka vode te pojačava značenja stihova središnjega dijela koji sadrže najveći broj vodnih riječi. Riječ more ponavlja se u prvom (s desne je strane ceste proljetno more), središnjem (u moru koje skupa sa mnom šuti) i posljednjem (ravnodušnost od koje me / zalud liječi more) dijelu pjesme.

Opozicija doseže vrhunac u središnjem dijelu pjesme u kojemu osjećaje ograničenosti, nepomičnosti, nijemosti te suhoće zemlje, žbuke, praha i kamena zamjenjuje mokrina i pomičnost vode, mora, šterne, zdenca, čistog neba, ribarske brodice, rukavca Drave, leda i inja. U tom središnjem dijelu pjesme dolazi do promjene: brojnost vodnih riječi kao da ispire/mijenja stav subjekta, kao da (se) konačno u jednom trenutku može vidjeti čisto nebo i osjetiti jedinstvo s mirnim morem.

Navedene glasovne figure uspostavljaju plošne/prostorne veze među pojedinim njezinim dijelovima, povezuju/poistovjećuju različite jezične sadržaje stvarajući slojevit, prostoran pjesnički znak te čine uočljivijom strukturu pjesme.

More iz naslova pjesme upućuje na izvanjezične sadržaje jer se more ponavlja na ključnim mjestima pjesme: u prvom dijelu pjesme, $s$ desne je strane ceste proljetno more, u središnjem dijelu, more koje skupa sa mnom šuti te u posljednjem dijelu, ravnodušnost od koje me/zalud liječi more. U prvom dijelu pjesme također uočavamo blizinu riječi umora (u tvojim očima) riječi (proljetno) more koje anagramskim postupkom upućuje na daljnja uočavanja ponavljanja riječi more. Središnji dio pjesme kao da okupljanjem vodnih riječi u nekoliko stihova predstavlja čistilište, odmorište ili bar utočište od umora, nijemosti, ravnodušnosti i skrivanja koja se uočavaju kao raspoloženja u ostatku pjesme.

Također je uočljivo ispreplitanje vodnih riječi iz različitih semantičkih skupina i njihovih semantičkih gnijezda. Iz semantičke skupine Zemljopisno vodno nazivlje, odnosno iz semantičkoga gnijezda Zemljopisno nazivlje vezano uz more, podmorje te dodir kopna i mora uočavamo vodnu imenicu more koja se u pjesmi ponavlja četiri puta te vodne imenice iz semantičkoga gnijezda Protočne vode - rukavac i zdenac. Iz semantičke skupine Ostali vodni leksemi, odnosno iz semantičkoga gnijezda Hidronimi, uočavamo hidronim Drava. Sudružje vodnih riječi iz različitih semantičkih skupina kazuje o presliku krajolika u tekst: $\mathrm{s}$ jedne strane more, s druge rukavac i zdenac - to je slika panonskoga prostora, tekstualna integriranost neposredno postojećih panonskih prostora (Drava, rukavac, zdenac) te onih memorijski upisanih (more) 
u prostornu konstituciju panonskoga prostora. Drugim riječima, očita je mogućnost nalaženja korespondencije između krajolika u kojemu Rešicki živi i stvara i njegova rukopisa. Brojnost vodnih riječi, njihova povezivost i središnjost u pjesničkome prostoru i prostoru pjesme, podupire tvrdnju o uvjetovanosti jezika prostorom i jezično-prostornom suživotu koji se uočava ne samo na leksičkoj, semantičkoj i gramatičkoj već i na fonostilističkoj jezičnoj razini.

\section{Zaključak}

Cilj ovoga rada bio je predstaviti, opisati i protumačiti leksičku brojnost izraza iz semantičkoga polja vode u pjesništvu Delimira Rešickog, poduprijeti tezu o uvjetovanosti jezika životnim prostorom te opisati integriranost konkretnoga geografskog prostora - Panonije u poetički identitet teksta. Rezultati četiriju analiza potvrdili su pretpostavku o važnosti kategorije prostora te umreženju geografije u interdisciplinarna istraživanja.

\section{Literatura}

Belaj, Branimir. „Prostorna značenja na razini složene rečenice.“ U Prostor u jeziku / Književnost i kultura šezdesetih. Zbornik radova 37. seminara Zagrebačke slavističke škole, ur. Krešimir Mićanović, Zagreb: Zagrebačka slavistička škola, accessed May 13, 2017 https://www.hrvatskiplus.org/article. php?id=2531\&naslov=prostor-u-jeziku-knjizevnost-i-kultura-sezdesetih.

Benčić Rimay, Tea. „Jeka opasnog prostora.“Vijenac, br. 301 (2005), accessed May 13, 2017 https://www.matica.hr/vijenac/301/JEKA OPASNOG PROSTORA/.

Brozović Rončević, Dunja. „Apelativi u hrvatskoj hidronimiji.“ Doktorska disertacija, Filozofski fakultet u Zagrebu, 1997.

Giljferding Fjodorovič, Aleksandar. Putovanje po Hercegovini, Bosni i Staroj Srbiji. Sarajevo: Veselin Masleša, 1972.

Grgas, Stipe. „Posvećenje prostora kao ljudska praksa.“ Glasje: časopis za književnost $i$ umjetnost, br. 13 (2003): 43-51.

Grgas, Stipe. Kažnjavanje forme: irsko pjesništvo poslije Yeatsa. Zagreb: Naklada MD, 2006.

Grgas, Stipe. „Bučno nadire prostor sa svih strana: Geografija u pjesništvu Adriane Škunca."U Muzama iza leđa: čitanje hrvatske lirike, ur. Tvrtko Vuković, 51-69. Zagreb: Zagrebačka slavistička škola, 2010.

Grgas, Stipe. „O hrvatskome spacijalnom imaginariju.“ U Mjesto, granica, identitet: Prostor u hrvatskoj književnosti i kulturi, ur. Lana Molvarec, 49-66. Zagreb: Zagrebačka slavistička škola, 2014. 
Gunaev, Z. S. „O vyrazenii prostranstvennix otnošenij v nekotoryx dagestanskix jazykax.“ Voprosy jazykoznanija, br. 6 (1977): 126.

Jukić, Sanja i Goran Rem. Panonizam I. Budimpešta - Osijek: Krešendo, 2014.

Magaš, Damir. Geografija Hrvatske. Zadar: Sveučilište u Zadru, Meridijani, 2013.

Paić, Žarko. „Praskozorja i ledeni grobovi, ogled uz zbirku pjesama Delimira Rešickog Aritmija.“ Riječi, br. 3/4 (2005): 94-99.

Pansini, Mihovil. „Koncept gramatike prostora.“ Govor, br. 5 (1988): 117-128.

Piper, Predrag. Jezik i prostor. Beograd: Biblioteka XX vek, 2001.

Pranjković, Ivo. Druga hrvatska skladnja. Sintaktičke rasprave. Zagreb: Hrvatska sveučilišna naklada, 2001.

Pranjković, Ivo. Gramatička značenja. Zagreb: Matica hrvatska, 2013.

Sorel, Sanjin. Mediteranizam tijela. Zagreb: altaGama, 2003.

Vuković, Tvrtko. „Prostornost Tadijanovićeve poezije: Uvod u spacionalističku analizu.“ U Tema Tadijanović. Zbornik o Dragutinu Tadijanoviću u povodu 95. pjesnikova rođendana, ur. Vinko Brešić, 13-19. Slavonski Brod: Matica hrvatska Slavonski Brod, 2002.

Vuletić, Dušanka. Istraživanje govora. Zagreb: Fakultet za defektologiju Sveučilišta u Zagrebu, 1991.

Vuletić, Branko. Fonetika književnosti. Zagreb: Sveučlišna naklada Liber, 1976.

Vuletić, Branko. Gramatika govora. Zagreb: GZH, 1980.

Vuletić, Branko. Sintaksa krika. Rijeka: Izdavački centar Rijeka, 1986.

Vuletić, Branko. Jezični znak, govorni znak, pjesnički znak. Zagreb: Izdavački centar Revija Radničkog sveučilišta Božidar Maslarić, 1988.

Vuletić, Branko. Prostor pjesme: o plošnom-prostornom ustrojstvu pjesništva Jure Kaštelana. Zagreb: Biblioteka „L“. Zavod za znanost o književnosti Filozofskoga fakulteta, 1999.

Vuletić, Branko. Fonetika pjesme. Zagreb: FF press, 2005.

Vuletić, Branko. Govorna stilistika. Zagreb: FF press, 2006.

Vuletić, Branko. Lingvistika govora. Zagreb: Ffpress, 2007.

Žužul, Ivana. ,Zaglavljeni u distopiji. Otok kao mjesto bez mjesta u Šoljanovu $\mathrm{Na}$ Pelegrinu i Karuzinu Vodiču po otoku." U Hvar - književnost $i$ kazalište, ur. Dubravko Jelčić, Boris Senker, i Vinka Glunčić-Bužančić, 341-360. Zagreb Split: Hrvatska akademija znanosti i umjetnosti - Književni krug, 2012.

\section{Izvori}

Rešicki, Delimir. Gnomi. Zagreb: cddssoh, 1985.

Rešicki, Delimir. Die die my darling. Zagreb: Biblioteka quorum, 1990.

Rešicki, Delimir. Knjiga o anđelima. Zagreb: Meandar, 1997.

Rešicki, Delimir. Ezekijelova kola. Zagreb: Bibliotek itd, 1999.

Rešicki, Delimir. Sretne ulice. Zagreb: Meandar, 2000.

Rešicki, Delimir. Aritmija. Zagreb: Meandar, 2005.

Rešicki, Delimir. Lovci u snijegu. Zagreb: Fraktura, 2015. 


\section{Linguistics and Geographics Spaces in the Poetry Written by Delimir Rešicki}

Summary: The paper analyzes the expressions from the semantic field of water in the poetry written by Delimir Rešicki. The analysis is preceded by a review of the existing scientific approaches to space as a condition for linguistic structure from the perspectives of linguistics and phonostilistics. In the analytical part of the paper, we will try to use the listed and from the linguistic and phonetic perspectives analyzed terms from the semantic field of water to support the thesis on the conditionality of language on the living space and emphasize the integrity of the particular geographical area of Pannonia in the poetic identity of the text.

Keywords: space, water lexic, spatial relationships, Delimir Rešicki, panonnism 